\title{
PENGARUH STERILAN TERHADAP TINGKAT KONTAMINASI PADA KULTUR PETIOL DAN MIDRIB DAUN TANAMAN KARET (HEVEA BRASILIENSIS MUELL ARG.) KLON PB 330
}

\author{
Effect of Sterilants to Contamination Level on Petiol and Midrib Culture \\ of PB 330 Rubber Clone (Hevea brasiliensis Muell Arg.) \\ Lestari ADMOJO dan Nur Eko PRASETYO \\ Balai Penelitian Getas, Pusat Penelitian Karet \\ Jalan Pattimura KM 6 Salatiga 50771 Jawa Tengah \\ Email: tariadmojo@gmail.com
}

Diterima:26 September 2016/Disetujui:19 Desember 2016/Diterbitkan:30 Desember 2016

\begin{abstract}
Tissue culture is one of new effort to improve rubber (Hevea brasiliensis Muell. Arg.) clonal propagation. However, one of the major problem is the high percentage of contamination during culture. Contamination is caused by some surface and systemic fungi and bacterial coming from the field. This experiment was conducted to investigate the effect of pre sterilization and sterilization treatments using fungicide Dithane $M-45$, $\mathrm{NaClO} 5.25 \%$ and $\mathrm{HgCl}_{2} \quad 0.2 \%$ and its combinations in petiole and midrib culture of rubber clone $P B$ 330. Explant was planted on MS+2,4-D (Dicholophenoxy acetic acid) $5 \mathrm{ppm}$ using 10 bottles as replication, each was planted with 2 explants/bottle. The observation was covering the percentage of contamination and deathly explants up to 14 Day After Culture (DAC). Data were analyzed by Analysis of Variance of Factorial Design and significant different among treatments were compared by Duncan Multiple Range Test (DMRT). The results of the current study revealed that the best treatment on midrib explant was pre sterilization (soaking explants on fungicide for 30 and 60 minutes before sterilization) combined by sterilization treatment (soaking on alcohol $70 \%$ and $\mathrm{NaClO}$ $5.25 \%$ for 3 minutes). The percentage of contamination culture was $21.33 \%$ and $21.67 \%$. Petiole culture showed 33\% contaminaton using pre sterilization (24 hour soaking on fungicide) combined by sterilization treatment (soaking explants on alcohol 70\%, $\mathrm{NaClO} \mathrm{5.25 \% ,} \mathrm{and} \mathrm{HgCl}_{2} \quad 0.2 \%$ for 3 minutes).
\end{abstract}

Keywords: Hevea brasiliensis; contamination; petiole; midrib; PB 330; sterilization

\section{Abstrak}

Kultur jaringan merupakan salah satu teknik perbanyakan tanaman yang perlu terus dikembangkan untuk tanaman karet klonal (Hevea brasiliensis Muell Arg.). Permasalahan yang masih harus diatasi adalah tingginya tingkat kontaminasi pada fase tanam. Kontaminasi terutama diakibatkan oleh banyaknya fungi dan bakteri yang menyelimuti baik di permukaan maupun di dalam sistem jaringan eksplan, yang biasanya berasal dari lapangan. Tujuan penelitian ini untuk mencari metode paling efektif dalam mengurangi tingkat kontaminasi pada kultur in vitro eksplan petiol dan midrib daun klon karet PB 330 melalui perlakuan pra sterilisasi, sterilisasi dan kombinasinya menggunakan fungisida Dithane $\mathrm{M}-45$, $\mathrm{NaClO} 5,25 \%$ dan $\mathrm{HgCl}_{2} \mathrm{O}, 2 \%$. Eksplan ditanam pada media MS+2,4-D (Dicholophenoxy acetic acid) 5 ppm sebanyak 10 botol sebagai ulangan, masing-masing 2 eksplan/botol. Pengamatan meliputi persentase kontaminasi dan kematian eksplan hingga 14 hari setelah tanam (HST). Data dianalisis dengan analisis ragam dari rancangan faktorial dan diuji lanjut dengan Uji Jarak Berganda Duncan (UJBD) untuk data yang berbeda nyata. Hasil penelitian menunjukkan penurunan kontaminasi pada eksplan midrib efektif dengan perlakuan pra sterilisasi dengan perendaman fungisida selama 30 atau 60 menit dikombinasikan dengan perlakukan sterilisasi dengan perendaman dalam alkohol $70 \%$ dan $\mathrm{NaClO}$ 5,25\% selama 3 menit. Perlakuan tersebut menghasilkan tingkat kontaminasi sebesar $21,33 \%$ dan 21,67\%. Kontaminasi pada eksplan asal petiol dapat ditekan hingga 33\% dengan perlakuan pra sterilisasi yaitu perendaman fungisida 24 jam 
dikombinasikan perlakukan sterilisasi dengan perendaman dalam alkohol $70 \%$, lalu $\mathrm{NaClO} 5,25 \%$, dan $\mathrm{HgCl}_{2} 0,2 \%$ masingmasing selama 3 menit.

Kata kunci: Hevea brasiliensis; kontaminasi; petiol; midrib; PB 330; sterilisasi

\section{PENDAHULUAN}

Syarat utama dalam perbanyakan secara kultur in vitro adalah kondisi aseptis, baik kondisi ruangan, peralatan, eksplan, media maupun teknisi. Pada kultur jaringan menggunakan eksplan jaringan vegetatif tanaman karet klonal, tingkat kontaminasi yang tinggi, terutama fungi, merupakan salah satu faktor yang membatasi perkembangan eksplan. Kemajuan hasil telah diperoleh pada perbanyakan tanaman karet secara in vitro menggunakan eksplan jaringan vegetatif tanaman karet klonal klon IRR 112 dan PB 330, yaitu terbentuknya kalus friabel hingga membentuk fase embrio globular, jantung dan torpedo. Fase embrio torpedo tersebut berpeluang besar untuk berkembang menjadi planlet dengan media yang sesuai, namun sayangnya persentase terbentuknya fase tersebut masih sangat rendah. Rendahnya persentase pembentukan kalus tersebut antara lain disebabkan masih tingginya tingkat browning dan kontaminasi, terutama kontaminasi jamur saat tanam dan kontaminasi bakteri endogen pada fase setelah tanam. Pada tanaman karet, kandungan getah pada hampir seluruh bagian tanaman bahkan sejak usia muda diduga berpengaruh pada tingkat kontaminasi in vitro, disamping kondisi lapangan yang memungkinkan tanaman rentan terkontaminasi fungi.

Antisipasi tingginya tingkat kontaminasi, beberapa percobaan pra sterilisasi dengan merendam eksplan dalam larutan fungisida, percobaan sterilisasi dengan $\mathrm{HgCl}_{2}$ dan $\mathrm{NaClO}$ dan kombinasinya telah dilakukan. Perendaman dalam larutan fungisida perlu dicoba setelah perlakuan penyemprotan tanaman donor di lapangan dan rumah kaca belum memberikan hasil yang memuaskan. Pada kultur tunas muda klon karet RRIC 100 dan 121, kontaminasi eksplan berhasil ditekan hingga $80 \%$ menggunakan $0,2 \% \mathrm{HgCl}_{2}$ selama 10 menit yang dikombinasikan dengan etanol $70 \%$ selama 1 menit, dibandingkan dengan menggunakan $\mathrm{NaClO}$ yang hanya menghasilkan eksplan steril sebanyak 50\% (Seneviratne, Flegmann \& Wijesekara, 1995). Pada beberapa tanaman, bahan sterilan $\mathrm{NaClO}$ sering digunakan karena terbukti efektif sebagai antimikroba. $\mathrm{NaClO}$ bekerja dengan memasuki jaringan hidup mikroba dan berperan dalam merubah biosintesis sel, memasuki metabolisme sel, merusak struktur fosfolipid, dan merusak jaringan organik pada sel-sel mikroba (Marion, Manhaes, Homero, Bajo \& Duque, 2012). Penggunaan $\mathrm{HgCl}_{2}$ dan $\mathrm{NaClO}$ untuk kultur tebu dilaporkan terbukti lebih efektif dibandingkan bahan sterilan lain (Tiwari, Tripathi, Lal \& Mishra, 2012). Penggunaan $\mathrm{NaClO}$ yang dikombinasikan dengan etanol $70 \%$ atau beberapa senyawa seperti $\mathrm{H}_{2} \mathrm{O}_{2}$, calcium hypochlorite, alkohol, fungisida, antibiotik dan bromine water mampu menghasilkan kultur steril pada beberapa tanaman hingga 95\% (Kaviani, 2015). Beberapa kombinasi pra sterilisasi dan sterilisasi tersebut perlu diuji coba pada kultur petiol dan midrib klon karet, karena aplikasi tunggal belum memberikan hasil yang memuaskan. Tujuan penelitian ini adalah mencari teknik pra sterilisasi dan sterilisasi yang paling efektif dalam mengurangi tingkat kontaminasi dan kematian pada kultur in vitro eksplan petiol dan midrib klon karet PB 330 di antara beberapa perlakuan pra sterilisasi, sterilisasi dan kombinasinya.

\section{BAHAN DAN METODE}

Penelitian telah dilakukan di Laboratorium Bioteknologi, Fakultas Biologi, Universitas Gadjah Mada, Yogyakarta dan Laboratorium Kultur Jaringan, Balai Penelitian Getas, dimulai pada bulan Juli hingga Oktober 2014. Bahan dan metode yang digunakan adalah:

\section{Bahan tanam dan sumber eksplan}

Bahan tanam menggunakan bibit polibeg klon karet PB 330 pada fase 1-2 payung daun. Bibit diperoleh dari Balai Penelitian Getas dan ditempatkan di Laboratorium Bioteknologi, UGM selama penelitian berlangsung. Bagian daun diambil dari tunas primer pada usia sekitar 5-8 hari setelah flush. Daun yang diambil adalah yang berwarna kehijauan dan sehat. 
Eksplan yang digunakan adalah bagian petiol (tangkai daun) dan midrib (pertulangan daun).

\section{Penyiapan Eksplan}

Daun yang telah diambil sebagai sumber eksplan selanjutnya disiapkan di Laboratorium. Pra sterilisasi secara umum dilakukan dengan pencucian daun dalam desinfektan cair di bawah air mengalir. Setelah bersih, daun dipotong pada bagian petiol dan midrib sepanjang $3-5 \mathrm{~cm}$ dan diperlakukan sesuai dengan perlakuan pra sterilisasi dan sterilisasi. Sebelum ditanam dalam media kultur, petiol dan midrib dipotong dengan ukuran 1 x $1,5 \mathrm{~cm}$ dan setelah perlakuan sterilisasi direndam dalam asam askorbat $100 \mathrm{mg} / \mathrm{L}$ steril selama 30 menit untuk mencegah browning sebelum ditanam dalam media. Media tanam menggunakan MS+2,4-D 5 ppm. Kultur ditanam sebanyak 2 eksplan per botol dan selanjutnya diinkubasi dalam ruang gelap total.

\section{Perlakuan}

Perlakuan yang diterapkan dalam penelitian meliputi pra sterilisasi menggunakan fungisida di ruang persiapan Laboratorium, dan sterilisasi di Laminar Air Flow (LAF). Matriks perlakuan disajikan dalam Tabel 1. Perlakuan kombinasi pra sterilisasi dan sterilisasi antara eksplan midrib dan petiol (Tabel 3) dibedakan berdasarkan hasil percobaan pra sterilisasi (Tabel 1) dan sterilisasi (Tabel 2).

Tabel 1. Matriks perlakuan pra sterilisasi Table 1. Matrix of pre-sterilization treatments

\begin{tabular}{|c|c|c|c|}
\hline No & $\begin{array}{l}\text { Eksplan } \\
\text { Explants }\end{array}$ & $\begin{array}{c}\text { Pra sterilisasi } \\
\text { (waktu perendaman fungisida) } \\
\text { (menit) } \\
\text { Pre sterilization } \\
\text { (fungicide soaking duration) } \\
\text { (minute) }\end{array}$ & $\begin{array}{l}\text { Sterilisasi } \\
\text { Sterilization }\end{array}$ \\
\hline \multirow{5}{*}{1.} & & 0 & \multirow{9}{*}{$\begin{array}{c}\text { Seluruh eksplan } \\
\text { disterilkan dengan } \\
\text { Alkohol } 70 \% \text { selama } 3 \\
\text { menit, lalu dibilas dengan } \\
\text { akuades steril selama } 1 \\
\text { menit sebanyak } 3 \text { kali. }\end{array}$} \\
\hline & & 30 & \\
\hline & Midrib & 60 & \\
\hline & & 120 & \\
\hline & & 1440 & \\
\hline \multirow{4}{*}{2.} & \multirow{4}{*}{ Petiol } & $\begin{array}{c}0 \\
30\end{array}$ & \\
\hline & & $\begin{array}{l}30 \\
60\end{array}$ & \\
\hline & & 120 & \\
\hline & & 1440 & \\
\hline
\end{tabular}

Tabel 2. Matriks perlakuan sterilisasi

Table 2. Matrix of sterilization treatments

\begin{tabular}{|c|c|c|c|c|}
\hline \multirow[t]{2}{*}{ No } & \multirow{2}{*}{$\begin{array}{l}\text { Eksplan } \\
\text { Explants }\end{array}$} & \multirow[t]{2}{*}{$\begin{array}{l}\text { Pra sterilisasi } \\
\text { Pre sterilization }\end{array}$} & \multicolumn{2}{|c|}{$\begin{array}{c}\text { Sterilisasi (menit) } \\
\text { Sterilization (minutes) }\end{array}$} \\
\hline & & & $\mathrm{NaClO}$ & $\mathrm{HgCl}_{2}$ \\
\hline \multirow{4}{*}{1.} & \multirow{4}{*}{ Midrib } & \multirow{8}{*}{$\begin{array}{l}\text { Seluruh eksplan dilakukan } \\
\text { pencucian dengan desinfektan } \\
\text { cair dan dibilas di bawah air } \\
\text { mengalir selama } 5 \text { menit. }\end{array}$} & 0 & 0 \\
\hline & & & 3 & 0 \\
\hline & & & 0 & 3 \\
\hline & & & 3 & 3 \\
\hline \multirow{4}{*}{2.} & \multirow{4}{*}{ Petiol } & & 0 & 0 \\
\hline & & & 3 & 0 \\
\hline & & & 0 & 3 \\
\hline & & & 3 & 3 \\
\hline
\end{tabular}


Tabel 3. Matriks perlakuan kombinasi pra-sterilisasi dan sterilisasi

Table 3. Matrix combination of pre sterilization and sterilization treatments

\begin{tabular}{|c|c|c|c|c|}
\hline \multirow{2}{*}{ No } & \multirow{2}{*}{$\begin{array}{l}\text { Eksplan } \\
\text { Explants }\end{array}$} & \multirow{2}{*}{$\begin{array}{c}\text { Pra sterilisasi } \\
\text { (waktu perendaman fungisida) } \\
\text { (menit) } \\
\text { Pre sterilization } \\
\text { (fungicide soaking duration) } \\
\text { (minute) }\end{array}$} & \multicolumn{2}{|c|}{$\begin{array}{c}\text { Sterilisasi (menit) } \\
\text { Sterilization (minutes) }\end{array}$} \\
\hline & & & $\mathrm{NaClO}$ & $\mathrm{HgCl}_{2}$ \\
\hline \multirow{5}{*}{1.} & \multirow{5}{*}{ Midrib } & 0 & 0 & 0 \\
\hline & & 30 & 3 & 0 \\
\hline & & 60 & 3 & 0 \\
\hline & & 30 & 0 & 3 \\
\hline & & 60 & 0 & 3 \\
\hline \multirow{3}{*}{2.} & \multirow{3}{*}{ Petiol } & 0 & 0 & 0 \\
\hline & & 60 & 3 & 3 \\
\hline & & 1440 & 3 & 3 \\
\hline
\end{tabular}

Pada perlakuan pra sterilisasi, seluruh eksplan selanjutnya disterilkan dengan alkohol $70 \%$ selama 3 menit lalu dibilas dengan akuades steril sebanyak 3 kali. Fungisida yang digunakan adalah Dithane M-45 dengan konsentrasi $10 \mathrm{~g} / \mathrm{L}$. Pada perlakuan sterilisasi, seluruh eksplan dicuci dengan desinfektan cair dan dibilas di bawah air mengalir selama 5 menit. Sterilan yang digunakan untuk perlakuan adalah Bayclin dengan konsentrasi $5,25 \% \mathrm{NaClO}$ dan larutan $\mathrm{HgCl}_{2} \quad 0,2 \%$ (v/v). $\mathrm{HgCl}_{2}$ diperoleh dari Merck, Jerman. Sterilisasi dilanjutkan dengan perendaman dalam alkohol $70 \%$ selama 3 menit dan 2 kali pembilasan dengan akuades steril setiap setelah perendaman dengan sterilan.

\section{Kondisi Kultur}

pH media kultur diatur sekitar 5,7-5,8. Selanjutnya media diautoklaf pada $121^{\circ} \mathrm{C}, 1$ atm. Kultur yang telah diberi perlakuan ditempatkan di ruang gelap, pada suhu $25^{\circ} \mathrm{C}$, kelembaban $60-70 \%$ dan batas waktu inkubasi hingga 14 HST (Hari Setelah Tanam).

\section{Rancangan Percobaan dan Pengamatan}

Percobaan pra sterilisasi dan sterilisasi digunakan sebagai uji pendahuluan untuk menentukan perlakuan kombinasi dan data disajikan dalam bentuk persentase kontaminasi dan kematian dari 20 eksplan yang ditanam. Selanjutnya berdasarkan data persentase tersebut ditetapkan perlakuan kombinasi. Perlakuan kombinasi pra sterilisasi dan sterilisasi disusun dengan Rancangan Faktorial dengan 3 ulangan, masing-masing ulangan sebanyak 10 botol. Data perlakuan kombinasi disajikan dalam bentuk rerata persentase jumlah eksplan yang mengalami kontaminasi dan jumlah eksplan yang mengalami kematian. Analisis data menggunakan analisis ragam dari rancangan faktorial, jika analisis ragam berbeda nyata maka dilakukan uji lanjut dengan DMRT (Duncan Mutiple Range Test) pada taraf $5 \%$. Data diamati hingga 14 HST.

\section{HASIL DAN PEMBAHASAN}

\section{Perlakuan Pra Sterilisasi Eksplan}

Hasil percobaan pra sterilisasi ditunjukkan dalam Tabel 4 dan Gambar 1. Perlakuan tersebut diikuti dengan sterilisasi di dalam LAF, yaitu mengkocok eksplan dalam alkohol $70 \%$ selama 3 menit, dan dibilas dalam akuades steril 2 kali. Hasil pengujian menunjukkan bahwa pada kultur petiol, perendaman fungisida selama 24 jam lebih baik dibandingkan perlakuan yang lainnya, dengan persentase tingkat kontaminasi mencapai $85 \%$ dan tingkat kematian eksplan mencapai $55 \%$ pada 14 HST. Perlakuan lain menunjukkan persentase tingkat kontaminasi dan kematian mencapai $100 \%$ pada 14 HST. Perlakuan perendaman fungisida selama 1 jam dan 24 jam selanjutnya dipilih untuk dikombinasikan dengan perlakuan sterilisasi. 
Tabel 4. Pengaruh fungisida terhadap tingkat kontaminasi dan kematian pada kultur petiol Table 4. Effect of fungicide on contamination level and mortality of petiole culture

\begin{tabular}{|c|c|c|c|c|c|}
\hline \multirow[t]{2}{*}{ No. } & \multirow{2}{*}{$\begin{array}{l}\text { Waktu } \\
\text { (Menit) } \\
\text { Time } \\
\text { (Minute) }\end{array}$} & \multicolumn{2}{|c|}{$\begin{array}{c}\text { Persentase kontaminasi } \\
\text { Percentage of contamination } \\
(\%)\end{array}$} & \multicolumn{2}{|c|}{$\begin{array}{l}\text { Persentase kematian } \\
\text { Percentage of death } \\
(\%)\end{array}$} \\
\hline & & $\begin{array}{l}7 \text { HST } \\
7 \text { DAC }\end{array}$ & $\begin{array}{l}14 \mathrm{HST} \\
14 D A C\end{array}$ & $\begin{array}{l}7 \text { HST } \\
7 D A C\end{array}$ & $\begin{array}{l}14 \mathrm{HST} \\
14 \mathrm{DAC}\end{array}$ \\
\hline 1. & 0 & 100 & 100 & 100 & 100 \\
\hline 2. & 30 & 100 & 100 & 70 & 100 \\
\hline 3. & 60 & 85 & 100 & 85 & 100 \\
\hline 4. & 120 & 85 & 100 & 60 & 100 \\
\hline 5. & 1440 & 55 & 85 & 30 & 55 \\
\hline
\end{tabular}

Keterangan (Remarks) : HST (Hari Setelah Tanam)/ DAC (Day After Culture)

Pada Gambar 1 menunjukkan pengaruh perendaman eksplan petiol dalam fungisida terhadap tingkat kontaminasi dan kematian eksplan petiol tersebut. Pada perlakuan perendaman selama 24 jam menunjukkan persentase tingkat kontaminasi dan kematian yang lebih rendah dibandingkan perlakuan lainnya.

Pada eksplan midrib daun, menunjukkan perendaman eksplan dalam larutan fungisida selama 60 menit lebih baik dibandingkan durasi waktu yang lain, dengan tingkat kontaminasi dan kematian mencapai $35 \%$ dan $45 \%$, diikuti dengan perendaman selama 30 menit yang mencapai $45 \%$ dan 55\% hingga pengamatan 14 HST (Tabel 5). Durasi waktu perendaman 60 menit dan 30 menit selanjutnya dipilih untuk dikombinasikan dengan perlakuan sterilisasi.

Gambar 2 menunjukkan grafik pengaruh perendaman fungisida terhadap tingkat kontaminasi dan kematian pada kultur midrib, dimana perlakuan durasi perendaman selama 60 menit menunjukkan persentase kontaminasi maupun persentase kematian yang lebih rendah dibanding perlakuan lainnya pada pengamatan 14 HST.

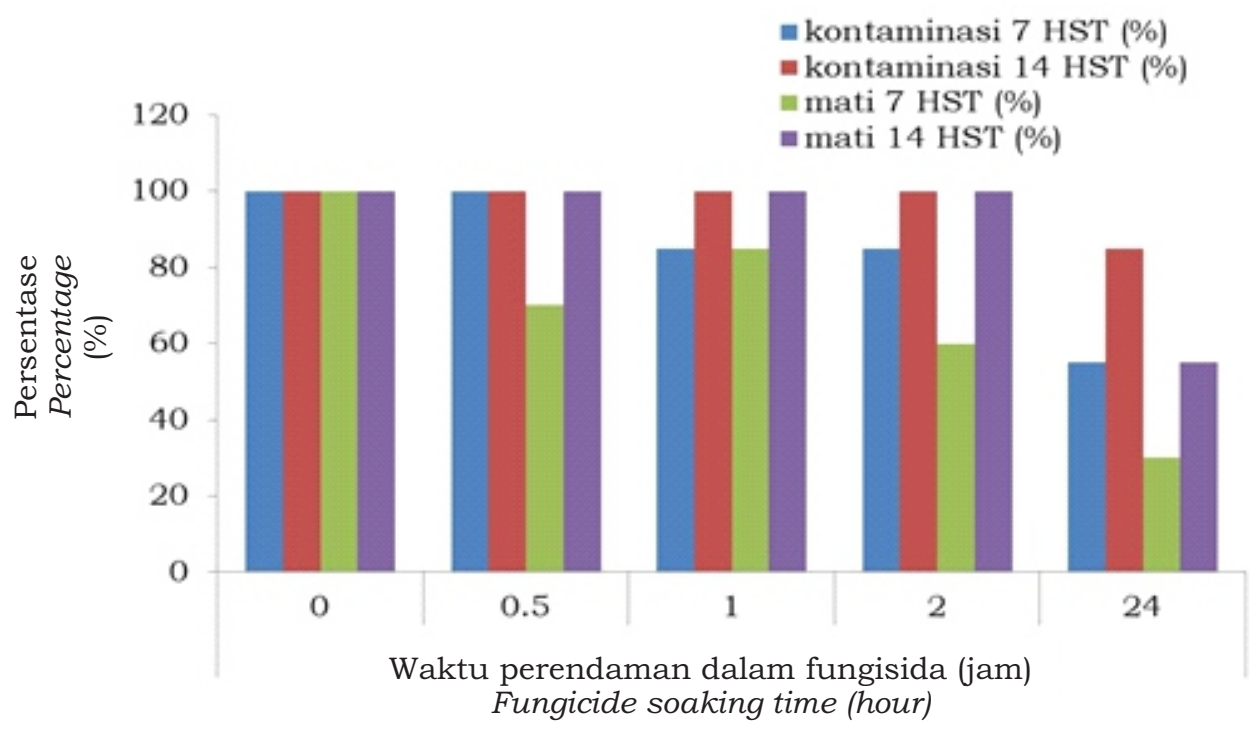

Gambar 1. Pengaruh fungisida pada tingkat kontaminasi dan kematian pada eksplan petiol Figure 1. Effect of fungicide on contamination level and mortality of petiole culture 


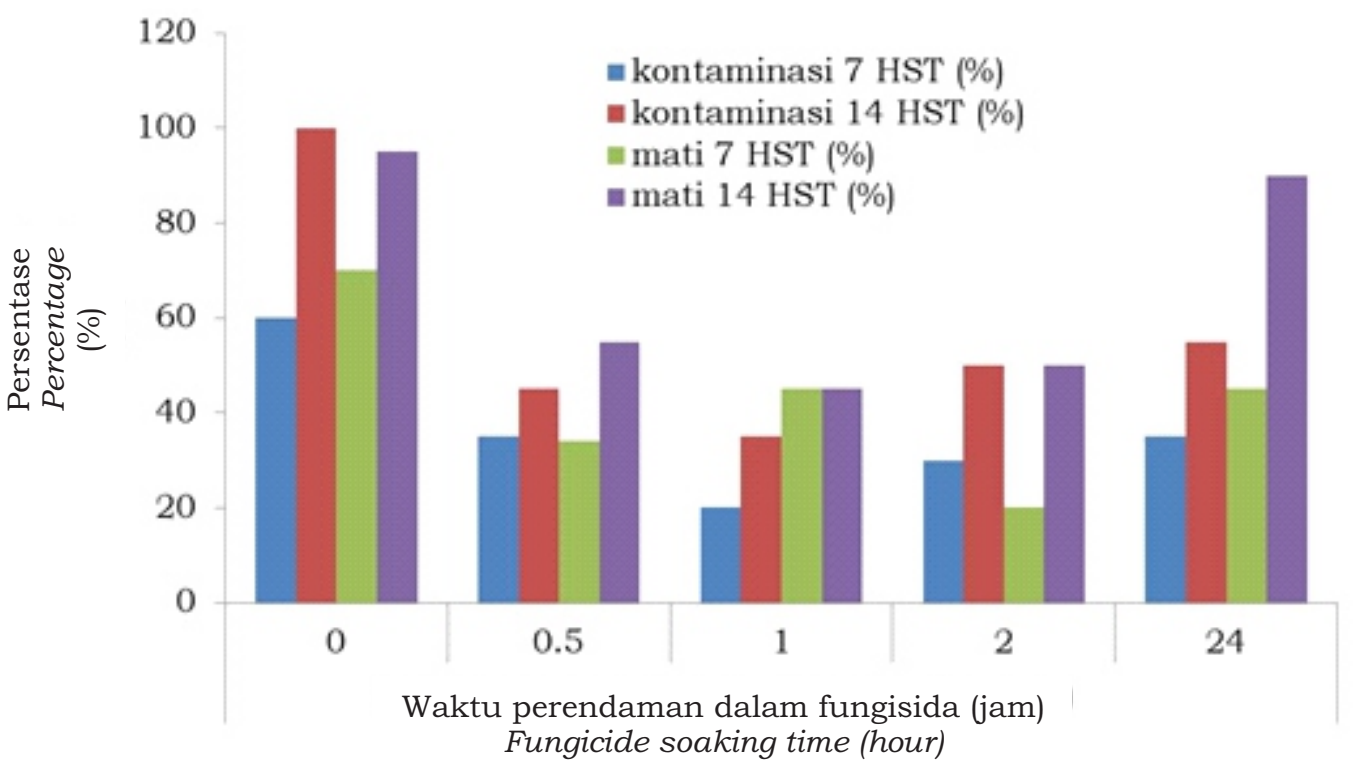

Gambar 2. Pengaruh fungisida pada tingkat kontaminasi dan kematian pada kultur midrib Figure 2. Effect of fungicide on contamination level and mortality of midrib culture

Eksplan petiol membutuhkan durasi waktu perendaman fungisida yang lebih lama dibandingkan eksplan midrib, diduga karena faktor kontaminan yang lebih banyak pada petiol akibat kandungan lateks yang berlebih. Pada beberapa kasus, perbedaan sumber eksplan membutuhkan teknik penanganan kontaminasi yang berbeda. Pada eksplan tunas pucuk tanaman $C$. latifolia dengan teknik sterilisasi yang sama menunjukkan persentase eksplan steril yang lebih baik dibandingkan eksplan asal petiol (Babaei, Abdullah, Saleh \& Abdullah, 2013). Konsentrasi fungisida untuk kultur aseptik menggunakan tunas apikal Japanese taro yang diuji pada kisaran 0-10 g/L menunjukkan bahwa penggunaan fungisida (Dithane M-45) sebanyak $10 \mathrm{~g} / \mathrm{L}$ menghasilkan tingkat kontaminasi yang rendah $(20 \%)$, perlakuan fungisida juga tidak berefek pada persentase dan waktu berkecambah serta browning (Haring, Musa, Sengin, Syahril \& Nasrun, 2014).

\section{Perlakuan Sterilisasi Eksplan}

Dalam bagian ini disajikan hasil sterilisasi eksplan tanpa perlakuan pra sterilisasi (eksplan sebelumnya hanya dicuci dalam desinfektan cair dan dibilas di bawah air mengalir). Setiap eksplan diletakkan dalam erlenmeyer steril, dan setiap perlakuan dikocok dalam alkohol $70 \%$ selama 3 menit lalu dibilas dalam akuades steril 2 kali (selama 2 menit) sebelum diperlakukan dalam larutan sterilan $\mathrm{NaClO}$ dan $\mathrm{HgCl}_{2}$. Setelah diperlakukan, eksplan selanjutnya dibilas dalam akuades steril sebanyak 2 kali dan ditanam dalam media. Hasil pengamatan pada kultur petiol menunjukkan bahwa perlakuan perendaman dengan sterilan $\mathrm{NaClO}$ dan $\mathrm{HgCl}_{2}$ masing-masing selama 3 menit memberikan hasil yang lebih baik untuk tingkat kontaminasi eksplan, yaitu sebanyak $65 \%$ pada 7 HST dan $90 \%$ pada 14 HST dibandingkan perlakuan lainnya. Persentase tingkat kematian masih tinggi akibat tingginya tingkat kontaminasi dan eksplan yang tidak merespon, yaitu mencapai $100 \%$ pada 14 HST (Tabel 6). Gambar 3 menunjukkan grafik pengaruh perendaman petiol dalam sterilan $\mathrm{NaClO}$ dan $\mathrm{HgCl}_{2}$ yang menunjukkan tingkat efektifitasnya terhadap kontaminasi dan kematian masih rendah, karena mencapai 80-100\%. Hasil tersebut menunjukkan bahwa perlakuan sterilisasi perlu dikombinasikan dengan perlakuan pra sterilisasi untuk lebih meminimalkan tingkat kontaminasi pada kultur petiol. Perlakuan sterilisasi dengan perendaman menggunakan sterilan $\mathrm{NaClO}$ dan $\mathrm{HgCl}_{2}$ masing-masing selama 3 menit selanjutnya dipilih untuk dikombinasikan dengan pra sterilisasi. 
Tabel 6. Pengaruh durasi perendaman $\mathrm{NaClO}$ dan $\mathrm{HgCl}_{2}$ terhadap tingkat kontaminasi dan kematian pada kultur petiol

Table 6. Effect of sterilant $\mathrm{NaClO}$ and $\mathrm{HgCl}_{2}$ on contamination level and mortality of petiole culture

\begin{tabular}{|c|c|c|c|c|c|c|}
\hline \multirow[t]{2}{*}{ No. } & \multicolumn{2}{|c|}{$\begin{array}{c}\text { Waktu } \\
\text { (menit) } \\
\text { Time } \\
\text { (minutes) }\end{array}$} & \multicolumn{2}{|c|}{$\begin{array}{c}\text { Persentase kontaminasi } \\
\text { Percentage of contamination } \\
(\%)\end{array}$} & \multicolumn{2}{|c|}{$\begin{array}{l}\text { Persentase kematian } \\
\text { Percentage of mortality } \\
(\%)\end{array}$} \\
\hline & $\mathrm{NaClO}$ & $\mathrm{HgCl}_{2}$ & $\begin{array}{l}7 \text { HST } \\
7 \text { DAC }\end{array}$ & $\begin{array}{l}14 \mathrm{HST} \\
14 \mathrm{DAC}\end{array}$ & $\begin{array}{l}7 \text { HST } \\
7 \text { DAC }\end{array}$ & $\begin{array}{l}14 \mathrm{HST} \\
14 \mathrm{DAC}\end{array}$ \\
\hline 1. & 0 & 0 & 100 & 100 & 75 & 100 \\
\hline 2. & 3 & 0 & 95 & 100 & 85 & 100 \\
\hline 3. & 0 & 3 & 80 & 95 & 75 & 90 \\
\hline 4. & 3 & 3 & 65 & 90 & 80 & 100 \\
\hline
\end{tabular}

Keterangan (Remarks) : HST (Hari Setelah Tanam)/DAC (Day After Culture)

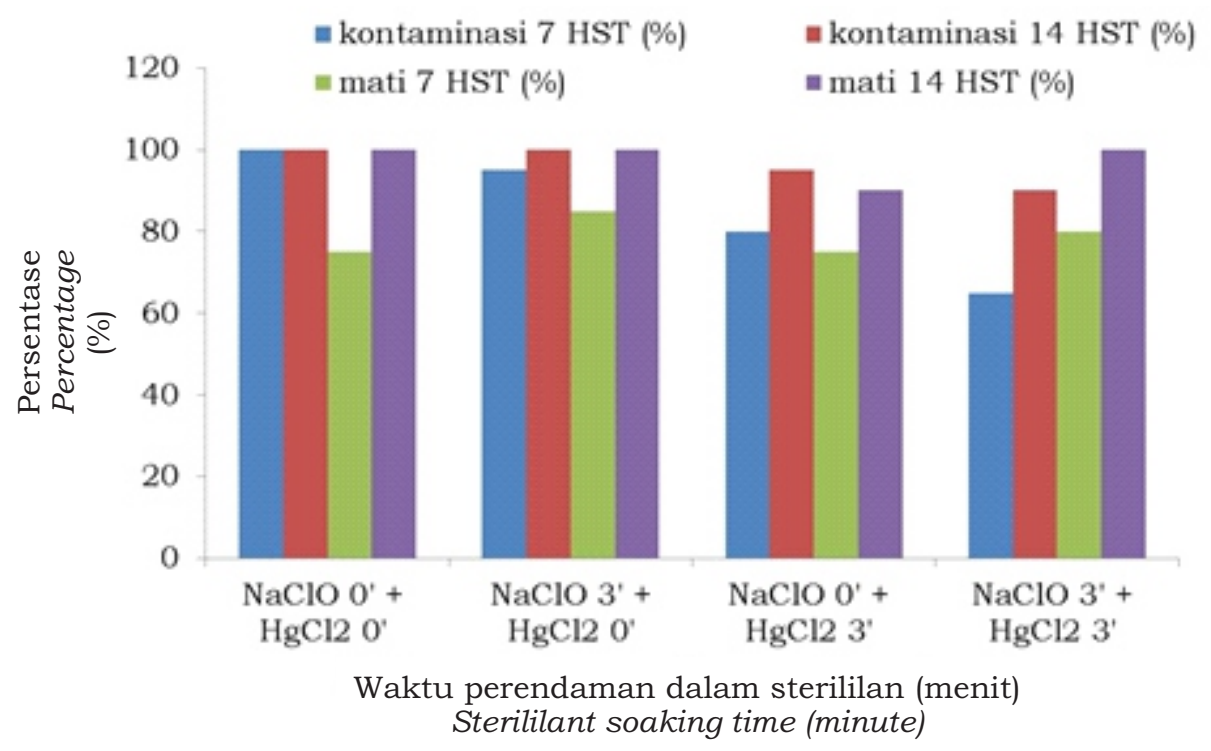

Gambar 3. Pengaruh perendaman sterilan terhadap tingkat kontaminasi dan kematian pada kultur petiol

Figure 3. Effect of sterilant on contamination level and mortality of petiole culture

Pada kultur midrib, perlakuan perendaman dalam kedua bahan sterilan $\mathrm{NaClO}$ dan $\mathrm{HgCl}_{2}$ masing-masing selama 3 menit menghasilkan tingkat kontaminasi sebesar $50 \%$ pada 7 HST, namun eksplan seluruhnya (100\%) mengalami kematian pada 14 HST. Pada perendaman menggunakan bahan sterilan tunggal $\mathrm{NaClO}$ selama 3 menit, menunjukkan tingkat kontaminasi yang lebih tinggi $(75 \%)$, namun dengan tingkat kematian lebih rendah $(50 \%)$. Hasil tersebut diduga penambahan $\mathrm{HgCl}_{2}, 0,2 \%$ memiliki toksisitas yang tinggi untuk eksplan midrib dibandingkan pada eksplan petiol. Gambar 4 menunjukkan grafik pengaruh perendaman midrib dalam sterilan $\mathrm{NaClO}$ dan $\mathrm{HgCl}_{2}$ yang menunjukkan perlakuan tunggal, yaitu hanya $\mathrm{NaClO}$ atau $\mathrm{HgCl}_{2}$ saja lebih baik untuk mengurangi tingkat kontaminasi, dibandingkan jika keduanya digunakan. Tingkat kematian eksplan masih lebih tinggi dengan penambahan $\mathrm{HgCl}_{2}$, sehingga penggunaan bahan sterilan tunggal dengan $\mathrm{NaClO}$ yang dikombinasikan dengan pra sterilisasi diduga memberikan hasil yang lebih baik untuk kultur midrib. 
Tabel 7. Pengaruh durasi perendaman $\mathrm{NaClO}$ dan $\mathrm{HgCl}_{2}$ terhadap tingkat kontaminasi dan kematian pada kultur midrib

Table 7. Effect of sterilant $\mathrm{NaClO}$ and $\mathrm{HgCl}_{2}$ on contamination level and mortality of midrib culture

\begin{tabular}{|c|c|c|c|c|c|c|}
\hline \multirow[t]{2}{*}{ No. } & \multicolumn{2}{|c|}{$\begin{array}{l}\text { Waktu } \\
\text { (menit) } \\
\text { Time } \\
\text { (minutes) }\end{array}$} & \multicolumn{2}{|c|}{$\begin{array}{c}\text { Persentase kontaminasi } \\
\text { Percentage of contamination } \\
(\%)\end{array}$} & \multicolumn{2}{|c|}{$\begin{array}{l}\text { Persentase kematian } \\
\text { Percentage of mortalilty } \\
(\%)\end{array}$} \\
\hline & $\mathrm{NaClO}$ & $\mathrm{HgCl}_{2}$ & $\begin{array}{l}7 \mathrm{HST} \\
7 \mathrm{DAC} \\
\end{array}$ & $\begin{array}{l}14 \mathrm{HST} \\
14 \mathrm{DAC}\end{array}$ & $\begin{array}{l}7 \mathrm{HST} \\
7 \mathrm{DAC}\end{array}$ & $\begin{array}{l}14 \mathrm{HST} \\
14 \mathrm{DAC}\end{array}$ \\
\hline 1. & 0 & 0 & 100 & 100 & 100 & 100 \\
\hline 2. & 3 & 0 & 50 & 75 & 35 & 50 \\
\hline 3. & 0 & 3 & 45 & 70 & 45 & 90 \\
\hline 4. & 3 & 3 & 20 & 50 & 50 & 100 \\
\hline
\end{tabular}

Keterangan (remarks) : HST (Hari Setelah Tanam)/ DAC(Day After Culture)

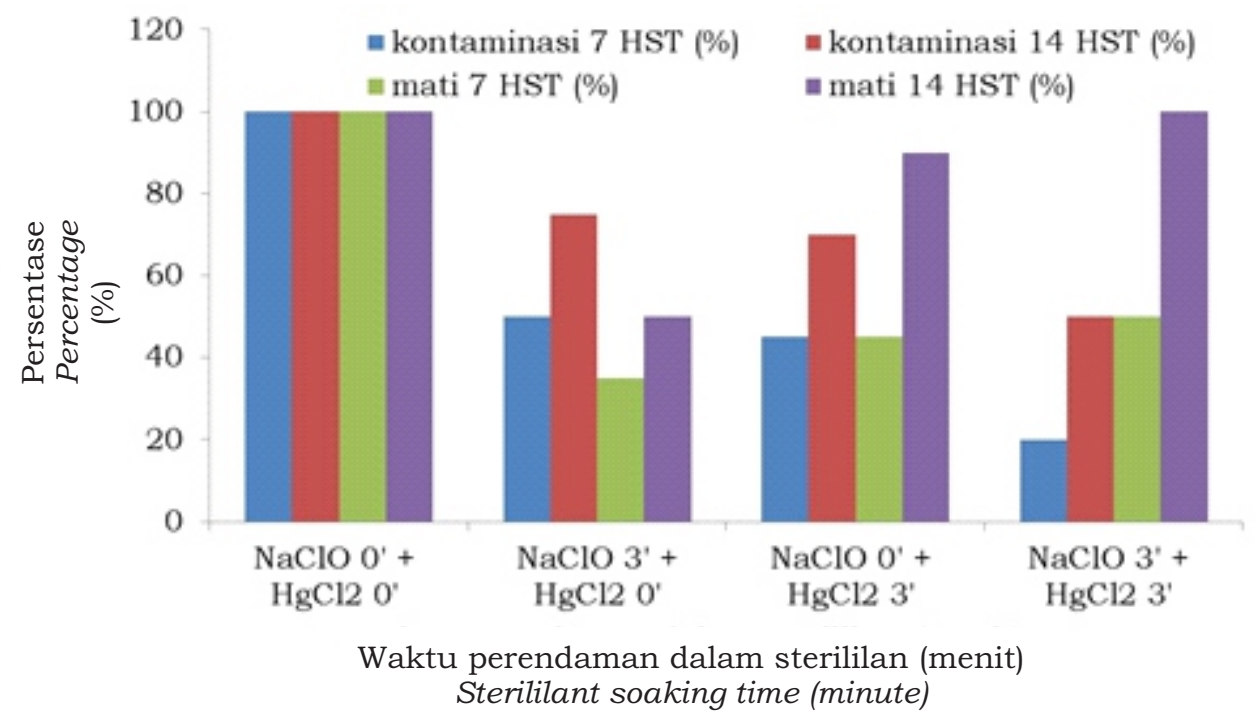

Gambar 4. Pengaruh perendaman sterilan ( $\mathrm{NaClO}$ dan $\mathrm{HgCl}_{2}$ ) terhadap tingkat kontaminasi dan kematian pada kultur midrib

Figure 4. Effect of sterilant ( $\mathrm{NaClO}$ and $\mathrm{HgCl}_{2}$ ) on contamination level and mortality of midrib culture

Kematian eksplan yang terjadi setelah perendaman dalam larutan $\mathrm{HgCl}_{2}$ 0,2\% kemungkinan disebabkan oleh aksi bleaching dari dua atom klorida dan ion-ion yang berikatan kuat dengan protein yang menyebabkan kematian organisme (Pauling, 1955 dalam Himabindu et al., 2012). Penggunaan bahan sterilan tunggal sering lebih baik untuk sterilisasi beberapa kultur tanaman, dibandingkan dengan beberapa bahan sterilan. Sterilisasi permukaan pada kultur ubi kayu juga menggunakan bahan sterilan tunggal $\mathrm{NaClO} 4 \%$ yang dikombinasikan dengan merendam eksplan sebanyak 3 kali dalam akuades steril, lalu direndam dalam $\mathrm{NaClO} 4 \%$ selama 30 menit. Teknik tersebut menghasilkan 21\% kontaminasi ( 3 dari 14 tabung terkontaminasi) (Manzanilla, 2015).

\section{Kombinasi Pra Sterilisasi dan Sterilisasi}

Kombinasi perlakuan ditentukan berdasarkan hasil yang diperoleh pada perlakuan pra sterilisasi (Tabel 2 dan 3) dan perlakuan sterilisasi (Tabel 4 dan 5), baik untuk kultur petiol maupun midrib. Pada kultur petiol, hasil percobaan menunjukkan bahwa perlakuan pra sterilisasi dengan perendaman dalam fungisida selama 24 jam yang dikombinasikan dengan sterilisasi 
menggunakan $\mathrm{NaClO}$ dan $\mathrm{HgCl}_{2}$ masingmasing selama 3 menit menunjukkan hasil yang terbaik (Tabel 8). Rata-rata tingkat kontaminasi dapat ditekan hingga 33\% pada 14 HST, berbeda nyata dengan perlakuan kontrol dan kombinasi perendaman larutan fungisida selama 1 jam. Tingkat kematian juga dapat ditekan bahkan hingga $0 \%$ pada 7 HST, meskipun meningkat menjadi $16,67 \%$ pada 14 HST.
Gambar 5 menunjukkan perbedaan yang nyata di antara perlakuan kombinasi pra sterilisasi dengan merendam dalam fungisida 24 jam dan sterilisasi dengan $\mathrm{NaClO}$ dan $\mathrm{HgCl}_{2}$, dengan perlakuan kontrol dan perlakuan pra sterilisasi selama 1 jam dan setrilisasi dengan $\mathrm{NaClO}$ dan $\mathrm{HgCl}_{2}$. Tingkat kontaminasi dan kematian eksplan nyata lebih rendah dibandingkan perlakuan lainnya.

Tabel 8. Pengaruh kombinasi pra sterilisasi dan sterilisasi terhadap tingkat kontaminasi dan kematian pada eksplan petiol

Table 8. Effect of pre sterilization and sterilization combination treatment on contamination level and mortality of petiole culture

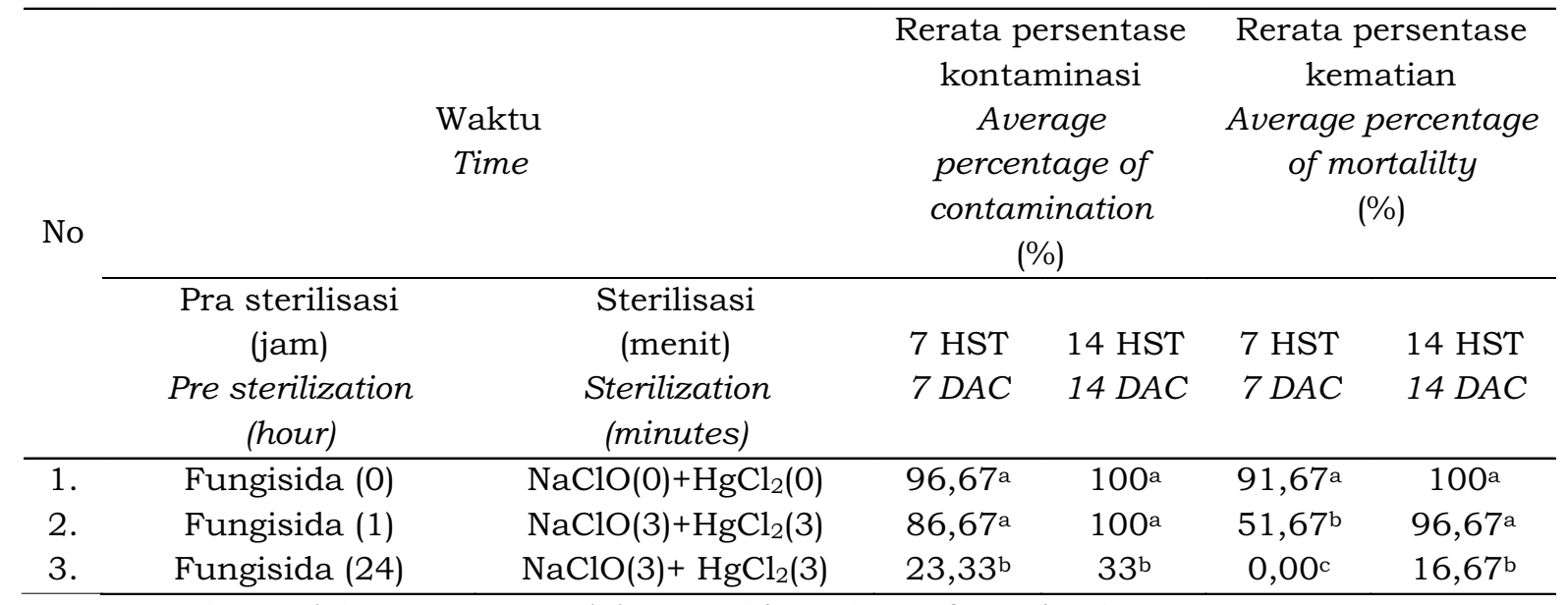

Keterangan (Remarks) : HST (Hari Setelah Tanam)/ DAC (Day After Culture)

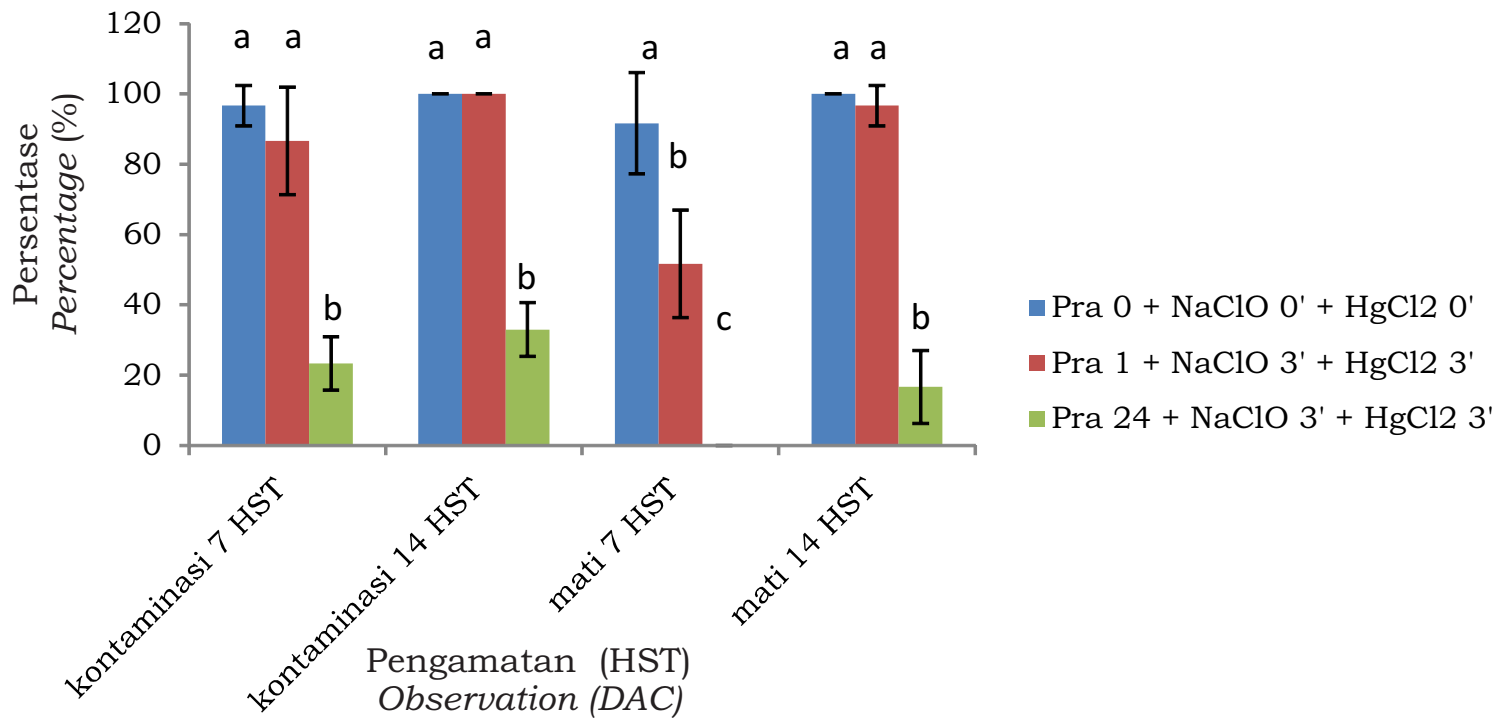

Gambar 5. Pengaruh kombinasi perlakuan pra sterilisasi dan sterilisasi terhadap tingkat kontaminasi dan kematian pada kultur petiol

Figure 5. Effect of pre sterilization and sterilization combination treatment on contamination level and mortality of petiole culture 
Pada kultur midrib, hasil menunjukkan bahwa perlakuan pra sterilisasi dengan merendam dalam fungisida selama 30 menit atau 60 menit yang dikombinasikan dengan sterilisasi menggunakan $\mathrm{NaClO}$ selama 3 menit menunjukkan hasil yang tidak berbeda nyata (Tabel 9). Rata-rata tingkat kontaminasi dapat ditekan hingga 21,33\% dan $21,67 \%$ pada 14 HST, berbeda nyata dengan perlakuan lainnya. Tingkat kematian juga dapat ditekan sebesar $11,67 \%$ dan $18,33 \%$ pada 14 HST, berbeda nyata dengan perlakuan lainnya.
Gambar 6 menunjukkan perbedaan yang nyata di antara perlakuan kombinasi pra sterilisasi fungisida pada 30 dan 60 menit dan sterilisasi $\mathrm{NaClO}$ selama 3 menit dengan perlakuan kombinasi lainnya. Tingkat kontaminasi dan kematian eksplan menunjukkan hasil yang nyata lebih rendah. Di antara kedua perlakuan tersebut, karena menunjukkan hasil yang tidak berbeda nyata, maka perlakuan pra sterilisasi dengan merendam dalam larutan fungisida selama 30 menit bisa dipilih karena membutuhkan waktu yang lebih singkat.

Dalam penelitiaan ini digunakan

Tabel 9. Pengaruh kombinasi pra sterilisasi dan sterilisasi terhadap tingkat kontaminasi dan kematian pada kultur midrib

Table 9. Effect of pre sterilization and sterilization combination treatment on contamination level and mortality of midrib culture

\begin{tabular}{|c|c|c|c|c|c|c|}
\hline \multirow[t]{3}{*}{ No. } & \multicolumn{2}{|c|}{$\begin{array}{c}\text { Waktu } \\
\text { (menit) } \\
\text { Time } \\
\text { (minutes) }\end{array}$} & \multicolumn{2}{|c|}{$\begin{array}{c}\text { Rerata persentase } \\
\text { kontaminasi } \\
\text { Average percentage of } \\
\text { contamination } \\
(\%)\end{array}$} & \multicolumn{2}{|c|}{$\begin{array}{c}\text { Rerata persentase } \\
\text { kematian } \\
\text { Average percentage of } \\
\text { mortality } \\
(\%)\end{array}$} \\
\hline & Pra sterilisasi & Sterilisasi & 7 HST & $14 \mathrm{HST}$ & $7 \mathrm{HST}$ & $14 \mathrm{HST}$ \\
\hline & Pre sterilization & Sterilization & $7 D A C$ & $14 D A C$ & $7 D A C$ & $14 D A C$ \\
\hline 1. & Fungisida (0) & (0) & $100^{\mathrm{a}}$ & $100^{a}$ & $90,0^{a}$ & $100^{a}$ \\
\hline 2 . & Fungisida (30) & $\mathrm{NaClO}(3)$ & $11,67^{b}$ & $21,33^{b}$ & $0,00^{c}$ & $11,67^{\mathrm{c}}$ \\
\hline 3. & Fungisida (60) & $\mathrm{NaClO}(3)$ & $0,00^{c}$ & $21,67^{b}$ & $0,00^{c}$ & $18,33^{c}$ \\
\hline 4. & Fungisida (30) & $\mathrm{HgCl}_{2}(3)$ & $0,00^{c}$ & $11,6^{b c}$ & $35,0^{b}$ & $61,67^{b}$ \\
\hline 5. & Fungisida (60) & $\mathrm{HgCl}_{2}(3)$ & $0,00^{c}$ & $8,3^{c}$ & $53,33^{b}$ & $71,67^{b}$ \\
\hline
\end{tabular}

Keterangan (Remarks) : HST (Hari Setelah Tanam)/ DAC(Day After Culture)

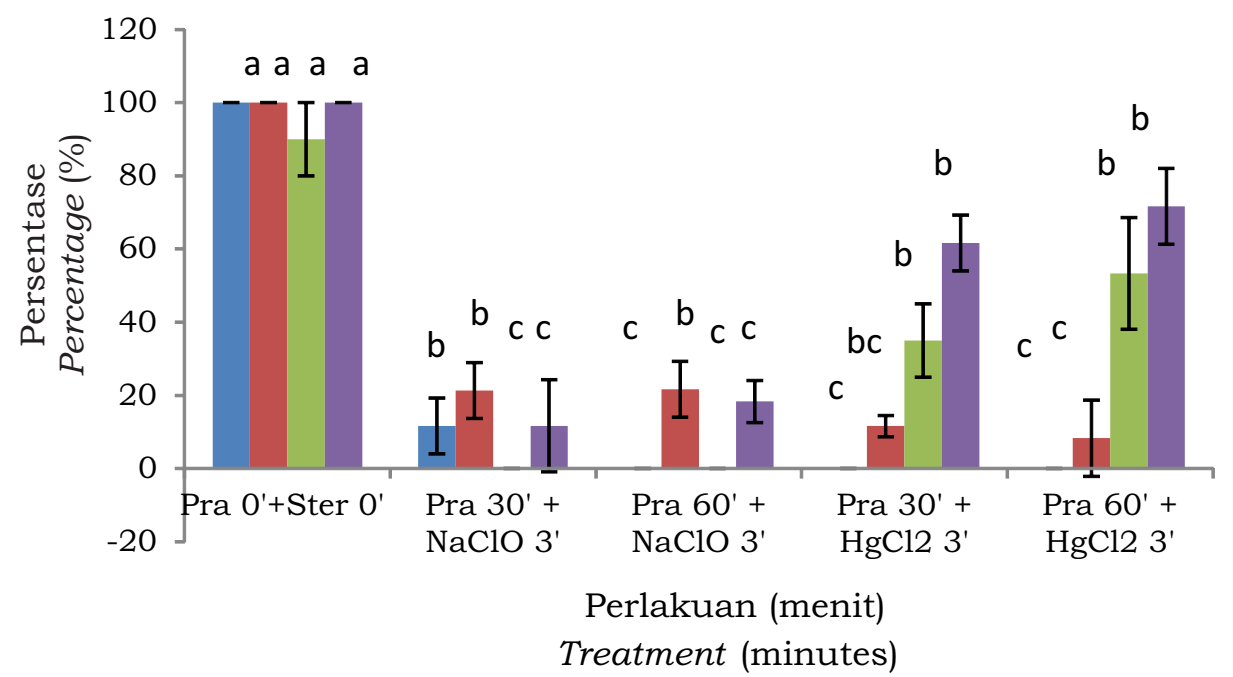

Gambar 6. Grafik pengaruh kombinasi perlakuan pra sterilisasi dan sterilisasi terhadap tingkat kontaminasi dan kematian pada eksplan midrib

Figure 6. Effect of pre sterilization and sterilization combination treatment on contamination level and mortality of midrib culture 
$\mathrm{NaClO} 5,25 \%$ selama 3 menit karena konsentrasi $\mathrm{NaClO}$ yang lebih tinggi biasanya membutuhkan waktu perendaman yang lebih singkat. Hasil review oleh Mario et al (2012) menyatakan bahwa semakin tinggi konsentrasi $\mathrm{NaClO}$ semakin sedikit waktu yang diperlukan dalam melawan bakteri sumber kontaminan. Konsentrasi 5,25\% membutuhkan waktu sekitar 2 menit untuk mematikan sel-sel hidup pada bakteri yang menyebabkan degradasi asam-asam amino dan hidrolisis yang memicu kematian bakteri sumber kontaminan. Efektivitas $\mathrm{NaClO}$ berhubungan dengan tingginya $\mathrm{pH}$ yang mengganggu integritas membran sitoplasma sel bakteri melalui mekanisme hambatan enzim yang bersifat irreversibel, merubah mekanisme biosintesis pada metabolisme sel dan merusak struktur fosfolipid. Inaktivasi enzim dapat teramati pada reaksi klorin dengan grup amino $\left(\mathrm{NH}_{2}{ }^{-}\right)$ dan oksidasi yang bersifat irreversibel pada grup sulfidril (SH) pada enzim bakteri (Estrela, Ribeiro, Estrela, Pecora \& SousaNeto, 2003).

Kombinasi pra sterilisasi dan sterilisasi seringkali dibutuhkan untuk mendapatkan eksplan steril yang optimal. Kombinasi beberapa bahan sterilan juga biasanya diperlukan pada beberapa kultur tanaman. Pada kultur batang bawah tanaman Pistachio UCB1, merendam eksplan dalam 15\% $\mathrm{NaClO}$ selama 5 menit diikuti dengan merendam dalam 0,01\% $\mathrm{HgCl}_{2}$ selama 7 menit cukup efisien menekan tingkat kontaminasi (Nezami, Yadollahi, Hokmabadi \& Eftekhari, 2015). Perlakuan dengan $\mathrm{NaClO} 5,25 \%$ hingga pada konsentrasi tinggi $(50 \% \quad \mathrm{NaClO})$ secara tunggal tidak cukup untuk mengontrol kontaminasi fungi dan bakteri pada eksplan A. malaccensis. Disimpulkan bahwa penggunaan bersama bahan sterilan $\mathrm{HgCl}_{2}$ bersama fungisida pada pra perlakuan menghasilkan efisiensi sterilisasi yang lebih baik yaitu pada kisaran 83-90\% untuk eksplan daun, nodal dan biji tanaman $A$. malaccensis yang diambil dari lapangan dan dikultur selama 40 hari (Daud, Jayaraman \& Mohamed, 2012). Pada kultur Salacia chinensis, sterilisasi permukaan dengan $70 \%$ etanol selama 1 menit dilanjutkan dengan $1 \% \mathrm{NaClO}$ (dengan ditambahkan 2-3 tetes Tween 20) selama 15 menit terbukti lebih efektif untuk eksplan daun yang mencapai 99\%, sedangkan direndam dalam $70 \%$ etanol selama 2 menit, diikuti dengan
$0,1 \%$ merkuri klorida $\left(\mathrm{HgCl}_{2}\right)$ selama 5 menit terbukti lebih efektif untuk eksplan nodal (96\%) (Majid et al., 2014).

Sterilisasi pada eksplan petiol membutuhkan bahan sterilan yang lebih banyak $\left(\mathrm{HgCl}_{2}\right.$ dan $\left.\mathrm{NaClO}\right)$ serta durasi waktu pra sterilisasi yang lebih lama (perendaman dengan fungisida selama 24 jam) dibandingkan dengan eksplan midrib, diduga karena petiol memiliki kandungan getah yang lebih banyak, sehingga menyimpan potensi kandungan mikroba yang lebih banyak dibandingkan bagian midrib. Enjalric et al. (1988) dalam Seneviratne et al. (1995), menyatakan terdapat sejumlah besar bakteri dan fungi yang berasosiasi dengan jaringan tanaman, yaitu sekitar 20 jenis berbeda yang menyebabkan sekitar 73\% infeksi penyakit pada tanaman karet, terutama pada bagian batang yang bergetah. Efektivitas penggunaan sterilan juga bergantung pada jenis dan jaringan eksplan yang digunakan. Pada kultur tunas kentang, terbukti penggunaan $\mathrm{NaClO} 1 \%$ menunjukkan hasil yang lebih baik dibandingkan dengan $\mathrm{HgCl}_{2}$ $0,1 \%$ pada rentang waktu perendaman yang sama, sedangkan pada bagian nodal tanaman Cestrum nocturnum L. menunjukkan 0,05\%-0,2\% $\mathrm{HgCl}_{2}$ lebih baik dibandingkan 50-60\% $\mathrm{NaClO}$ (Mahmoud \& Al-Ani, 2016). Mekanisme $\mathrm{HgCl}_{2}$ dalam mencegah aktivitas mikroba yaitu dengan menurunkan aktivitas protein akibat mekanisme pengikatan grup thiol (-SH). Merkuri dapat menonaktifkan sejumlah enzim dengan menangkal sisi fungsional yang berikatan dengan grup - $\mathrm{SH}$ yang merupakan bagian katalitik enzim. Merkuri dapat menginduksi peningkatan akumulasi dari reactive oxygen species (ROS) pada sel, meningkatkan peroksidasi lipid, degradasi protein, dan menyebabkan kematian sel (Rao \& Patel, 2013).

Gambar 7 menunjukkan beberapa eksplan yang tidak mengalami kontaminasi maupun kematian hingga pengamatan 14 HST. Beberapa eksplan tidak mengalami kontaminasi namun mengalami kematian yang ditunjukkan dengan respon jaringan yang mencokelat atau menghitam hingga pengamatan 14 HST. Sebagian eksplan mengalami kontaminasi jamur yang ditunjukkan adanya miselia (serabutserabut putih yang melingkupi eksplan dan cepat menyebar dalam waktu beberapa 

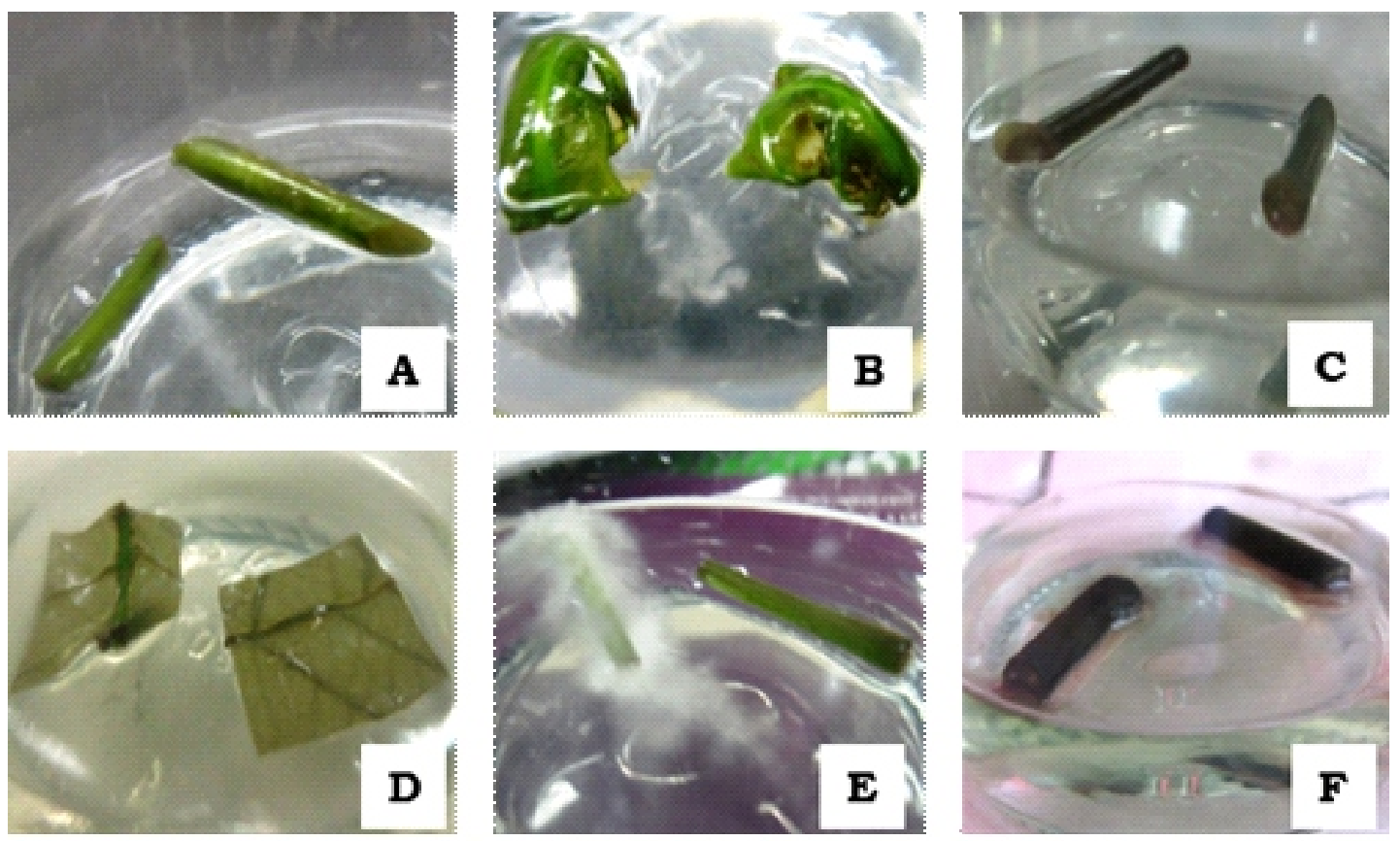

Gambar 7. Kultur yang tidak mengalami kontaminasi dan kematian pada eksplan petiol (A) dan midrib (B) pada 14 HST. Kultur yang tidak mengalami kontaminasi namun mengalami kematian pada eksplan petiol (C) dan midrib (D) pada 14 HST. Kultur petiol yang mengalami kontaminasi jamur (E) dan bakteri $(\mathrm{F})$ pada $14 \mathrm{HST}$.

Figure 7. No contamination and no death cultures on petiole (A) and midrib (B) for 14 DAC. No contamination but death cultures on petiole $(C)$ and midrib $(D)$ for 14 DAC. Fungal contamination on petiole culture $(E)$ and bacterial contamination on petiole culture $(F)$ for $14 D A C$.

hari), serta kontaminasi bakteri yang ditunjukkan adanya selaput lendir keputihan hingga kecokelatan pekat di sekitar eksplan, dan biasanya menyebabkan kematian eksplan dalam waktu singkat.

\section{KESIMPULAN}

Pencegahan kontaminasi pada eksplan midrib daun klon karet PB 330 efektif dilakukan dengan pra sterilisasi (perendaman eksplan dalam larutan fungisida selama 30 atau 60 menit) yang dikombinasikan dengan perlakukan sterilisasi (perendaman eksplan dalam alkohol $70 \%$ dan $\mathrm{NaClO} 5,25 \%$ selama 3 menit). Perlakuan tersebut menghasilkan tingkat kontaminasi sebesar 21,33\% dan $21,67 \%$. Kontaminasi pada eksplan petiol dapat ditekan hingga 33\% dengan perlakuan pra sterilisasi (perendaman eksplan dalam larutan fungisida selama 24 jam) dikombinasikan perlakukan sterilisasi (perendaman dalam alkohol 70\%, lalu $\mathrm{NaClO}$ $5,25 \%$ dan $\mathrm{HgCl}_{2} \quad 0,2 \%$ masing-masing selama 3 menit). Perlakuan tersebut menggunakan bibit yang ditempatkan bukan di daerah pembibitan karet. Kondisi tanaman normal dan tidak terserang penyakit sekalipun tidak pernah dilakukan penyemprotan fungisida.

\section{UCAPAN TERIMA KASIH}

Ucapan terima kasih kami sampaikan kepada Laboratorium Bioteknologi Fakultas Biologi Universitas Gadjah Mada yang telah memberikan fasilitas memadai bagi proses penelitian yang telah dilakukan. 


\section{DAFTAR PUSTAKA}

Babaei, N., Abdullah, N. A. P., Saleh, G. \& Abdullah, T. L. (2013). Control of contamination and explant browning in Curculigo latifolia in vitro cultures. Journal of Medicinal Plants., 7(8), 448454. Doi: $10.5897 / J M P R 012.859$.

Daud, N. H., Jayaraman, S. \& Mohamed, R. (2012). Methods paper: An improved surface sterilization technique for introducing leaf, nodal and seed explants of Aquilaria malaccensis from field sources into tissue culture. AsiaPasific Journal of Molecular Biology and Biotechnology, 20(2), 55-58.

Estrela, C., Ribeiro, R. G., Estrela, C. R. A., Pecora, J. D. \& Sousa-Neto, M. D. (2003). Antimicrobial effect of $2 \%$ sodium hypochlorite and $2 \%$ chlorhexidine tested by different methods. Brazilian Dental Journal, 14(1), 58-62. Doi: 10.1590/S010364402003000100011 .

Haring, F., Musa, Y., Sengin, E. L., Syahril, R. \& Nasrun, M. (2014). Aseptic culture of apical bud of Japanese taro $(C$. esculenta var. antiqourum) in various pesticides concentration. International Journal of Scientific \& Technology Research, 3(8), 64-67.

Himabindu, K. B., Priya, M. S., Reddy, D. M., Sudhakar, P., Srinivasulu, Y., Reddisekhar, M., Latha, P. \& Reddy, B. R. K. (2012). Studies on the effect of various sterilants and culture conditions on in-vitro seed germination in Tomato (Solanum lycopersicum). International Journal of Applied Biology and Pharmaceutical Technology, 3(4), 476-480.
Kaviani, B. (2015). Some useful information about micropropagation. Journal of Ornamental Plants, 5(1), 29-40.

Mahmoud, S. N., \& Al-Ani, N. K. (2016). Effect of different sterilization methods on contamination and viability of nodal segments of Cestrum nocturnum L. International Journal of Research Studies in Biosciences, 4(1), 4-9. Doi: 10.20431/2349-0365.0401002.

Majid, B. N., Roopa, G, Sampath, K. K. K., Kini, R. K., Prakash, H. S., Abbagani, S., Mehdi, K. \& Geetha, N. (2014). Establishment of an efficient explant surface sterilization protocol for in vitro micropropagation of Salacia chinensis L., an endangered anti-diabetic medicinal plant. World Journal of Pharmacy and Pharmaceutical Science, 3(12), 1266-1274.

Manzanilla, L. (2015). Surface sterilization for the establishment in-vitro of cassava (Manihot esculenta) (Thesis), University of Belize, Belize.

Marion, J. J. C., Manhaes, F. C., Bajo, H. \& Duque, T. M. (2012). Efficiency of different concentration of sodium hypochlorite during endodontic treatment. Dental Press Endodontics, 2(4),32-37.

Nezami, S. R., Yadollahi, A., Hokmabadi, H. \& Eftekhari, M. (2015). Control of shoot tip necrosis and plant death during in vitro multiplication of Pistachio rootstock UCB1 (Pistachia.integrima X Pistachia atlantica). Journal of Nuts, 6(1), 27-35. 
Rao, M. V. \& Patel, T. A. (2013). Protective effect of curcumin on mercuric chloride induced oxidative stress in rats. Indian Journal of Applied Research, 3(11), 541-543.

Seneviratne, P., Flegmann, A. W. \& Wijesekara, G. A. S. (1995). The problem of surface sterilization of shoot materials of hevea. Journal of Rubber Research of Sri Lanka, 75(1), 51-60.
Tiwari, A. K., Tripathi, S., Lal, M. \& Mishra, S. (2012). Screening of some chemical disinfectants for media sterilization during in vitro micropropagation of sugarcane. International Journal of Sugar Crops and Related Industry, 14(4), 364-369. Doi: 10.1007/s12355012-0178-5. 